\title{
The rectum as viewed by the venereologist*
}

\author{
R R WILLCOX \\ From the Department of Venereology, St Mary's Hospital, London
}

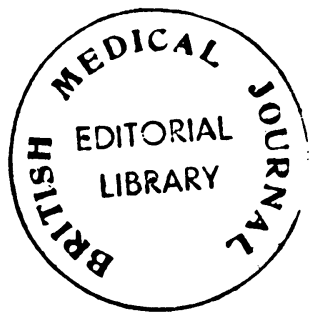

SUMMARY About 2-2 $1 / 2$ million people do, or will repeatedly, participate in ano-rectal sexual intercourse in Britain alone. The anus and the rectum of these individuals are thus vulnerable to all the sexually transmitted diseases (except trichomoniasis). Male homosexuals appear to be more prone to these conditions than female heterosexuals, possibly because a large minority is indiscriminately promiscuous. Over the last 20 years homosexually acquired infections-particularly syphilis-have increased in Britain; these are now more readily admitted to because of changes in the law and in public opinion. The frequent changes of sexual partner among male homosexuals is the most notable epidemiological factor in the spread of venereal disease.

\section{Introduction}

The complexity and variety of the sexual act is shown in the figure. The anus and rectum of homosexual women are at little risk of venereal infection, but in some heterosexual women and nearly all homosexual men, being recipients of the male organ, the risks are much greater.

Estimates of numbers of wholly homosexual men vary, but $4-5 \%$ is a common figure. ${ }^{12}$ If related to the $27 \cdot 2$ million men of the 1978 population of $55 \cdot 8$ millions in the United Kingdom this would suggest there are at least 1.1-1.4 million British homosexual men who actually do, or are potentially likely to, use either their own rectum or that of another person for sexual gratification.

Among heterosexual men the number of rectal users is known to be high among male patients attending venereal disease clinics. In one investigation $25-34 \%$ of such patients in Chicago, USA, and Kingston, Jamaica, had had heterosexual rectal coitus at least once, ${ }^{3}$ while in a study of female gonorrhoea contacts in London $17 \%$ had had rectal coitus within the previous three months. ${ }^{4 a}$

Data for the population at large are more scanty, although in one study the figure of $3 \%$ has been

* Paper presented at a joint meeting of the Medical Society for the Study of Venereal Diseases and the Section of Proctology, Royal Society of Medicine, London, 27 February 1980

Address for reprints: Dr R R Willcox, Tideway, Lonsdale Road, London SW13

Accepted for publication 14 March 1980

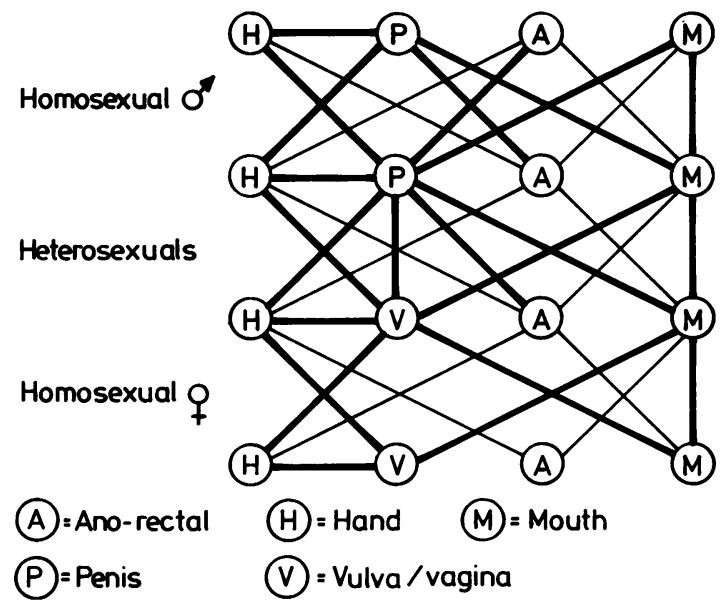

FIGURE Sexual behaviour

mentioned. ${ }^{2}$ If a figure of $2 \%$ was applied to the $28 \cdot 6$ million women in the United Kingdom, 572000 would have-or might have sometime in the future-anal intercourse. If a similar figure was applied to the remaining $25 \cdot 8-26 \cdot 1$ million heterosexual men this would imply a further $516000-522000$ men. Thus, if the basic assumptions are correct, this would amount to a total of $2-21 / 2$ million actual or potential rectal users in the United Kingdom. This may be regarded as the lowest estimate. In the United States the number of habitual and occasional homosexual men has been estimated at 30 millior. $^{4 b}$ 
The anus and rectum might, therefore, be expected to bear the brunt of much venereal disease. Although for some years now the rectum has been officially recognised as a genital organ by the Department of Health and Social Security (which requires the statistical classification of gonococcal and nongonococcal proctitis as genital infections) an increased awareness of this possibility is nevertheless required by both the public and the medical profession.

\section{Gonococcal infections of the rectum}

\section{WOMEN}

Rectal gonorrhoea in women was described in the 1930 s and was diagnosed in $30-55 \%$ of those with genital gonorrhoea ${ }^{5}$ by smear ${ }^{6}$ and also sometimes by culture. ${ }^{7}$ It was largely asymptomatic and persisted for some months without (and even with) some local treatments. ${ }^{67}$

In the 1930s and 1940s the accepted mode of infection of the female rectum with gonorrhoea was secondary to genital infection, ${ }^{568}$ since gonococcal pus contaminated the anus and the normal eversion of the anus during defecation allowed the terminal rectum to be infected as it retracted. ${ }^{6}$ Other modes of infection listed by Martin in 1935 included the wearing of tight undergarments, contamination of the anus with infected urine, the partial expulsion and retraction of a faecal mass (especially in constipated women), the backflow of a vaginal douche, contamination of rectal or vaginal specula or dilators and rectal thermometers, and the insertion of a suppository with infected fingers. All of these theories preceded that of peno-anal coitus and associated rectal disease. ${ }^{6}$

In the early 1950s Jensen found that $40 \%$ of patients with rectal gonorrhoea questioned in Copenhagen admitted to rectal coitus ${ }^{9}$ and noted that a more "biological" mode of infection than those previously considered seemed "rather foreign to the Anglo-American trend of thought." This trend largely persisted through the 1960s, when it was categorically affirmed that rectal gonorrhoea in women was not due to "unnatural sexual practices" 10 and has been widely prevalent until the present time.

MEN

Similarly, there was a reluctance to accept rectal infections in men, although Harkness, in 1948, had described 168 cases of primary gonococcal proctitis (the majority with few or no symptoms) resulting from sodomy, which he considered was much more frequent than generally supposed. ${ }^{11}$ In the same year
Nicol stated that rectal gonorrhoea, while common in women, was rare in $\operatorname{men}^{5}$; three years later McLachlan affirmed that such infections in men might follow the rupture of a prostatic abscess, an abscess of Cowper's gland, or a posterior periurethral abscess, or result "less frequently from sodomy". ${ }^{12}$

A decade later, however, the first evidence of change occurred in the West End of London. In 1962, at the West London Hospital, 6.9\% of gonococcal infections were found in homosexuals; two years later the figure had increased to $15 \cdot 5 \%$ (about half being ano-rectal infections), with possible increases to come, ${ }^{13}$ while similar findings were noted at St Mary's Hospital. ${ }^{14}$

In a more recent study by the British Co-operative Clinical Group of 36242 cases of gonorrhoea in $1971,{ }^{15}$ the respective percentages of infections which were acquired in Wales, Scotland, and English clinics outside London were $4 \cdot 0,4 \cdot 1$, and $4 \cdot 6 \%$ respectively; but higher figures of $\mathbf{7 . 7 \%}$ for the London clinics outside the West End and of $27.6 \%$ for five clinics in the West End were by then apparent.

A further study of 33826 cases in $1977^{16}$ showed $5.9 \%$ in Northern Ireland (not previously studied), $6.0 \%$ in English clinics outside London, $6.2 \%$ in Scotland, and $7 \cdot 3 \%$ in Wales. In London clinics outside the West End the figure was now $8.8 \%$ and in the five West End clinics $28 \cdot 7 \%$ (table I). Although only $30.4 \%$ of the total infections in Britain were treated in London (10 296 of 33826 ), no less than $61.5 \%$ of the homosexually acquired infections (2266 of 3687) were encountered in the capital.

Furthermore, while there was a decrease of 2554 $(7 \cdot 8 \%)$ of heterosexually acquired infections between the two studies there was a rise of 138 $(3.9 \%)$ of those contracted homosexually, most of which were ano-rectal infections (table II).

\section{Syphilis and the rectum}

\section{LATE SYPHILIS}

At the turn of the century syphilis was about the only venereal disease listed as affecting the rectum and then only indirectly in the rectal crises of tabes dorsalis and in terms of gummatous late syphilis. ${ }^{17}$ However, as the various manifestations of lymphogranuloma venereum (including inflammatory stricture of the rectum) were brought together as one entity in the mid-1930s, ${ }^{18}$ for the next decade the subject of syphilis of the rectum was confused by the expansion of knowledge of this new disease. ${ }^{19}$ It gradually became evident that practically all, if not all, of so-called tertiary syphilis of the rectum was in fact lymphogranuloma venereum, albeit occurring in patients with latent syphilitic disease. 
TABLE I Homosexually acquired gonococcal infections 1516

\begin{tabular}{|c|c|c|c|c|c|c|}
\hline \multirow[b]{3}{*}{ Area } & \multicolumn{3}{|l|}{1971} & \multicolumn{3}{|l|}{1977} \\
\hline & \multirow{2}{*}{$\begin{array}{l}\text { Total } \\
\text { infections }\end{array}$} & \multicolumn{2}{|c|}{ Homosexually acquired } & \multirow{2}{*}{$\begin{array}{l}\text { Total } \\
\text { infections }\end{array}$} & \multicolumn{2}{|c|}{ Homosexually acquired } \\
\hline & & No & $\%$ & & No & $\%$ \\
\hline $\begin{array}{l}\text { England } \\
50000 \text { or less } \\
50001-100000 \\
100001-500000 \\
500001 \text { plus } \\
\text { Total outside London }\end{array}$ & $\begin{array}{r}1102 \\
3379 \\
8852 \\
6590 \\
19923\end{array}$ & $\begin{array}{r}57 \\
168 \\
495 \\
202 \\
922\end{array}$ & $\begin{array}{l}5 \cdot 2 \\
5 \cdot 0 \\
5 \cdot 6 \\
3 \cdot 1 \\
4 \cdot 6\end{array}$ & $\begin{array}{r}1481 \\
4378 \\
9178 \\
4168 \\
19205\end{array}$ & $\begin{array}{r}76 \\
197 \\
681 \\
193 \\
1147\end{array}$ & $\begin{array}{l}5 \cdot 1 \\
4 \cdot 5 \\
7 \cdot 4 \\
4 \cdot 6 \\
6 \cdot 0\end{array}$ \\
\hline $\begin{array}{l}\text { London } \\
\text { Outside West End } \\
5 \text { West End clinics } \\
\text { Total London }\end{array}$ & $\begin{array}{r}4823 \\
582 \\
12405\end{array}$ & $\begin{array}{r}373 \\
2095 \\
2468\end{array}$ & $\begin{array}{r}7 \cdot 7 \\
27 \cdot 6 \\
19 \cdot 9\end{array}$ & $\begin{array}{r}3456 \\
6840 \\
10296\end{array}$ & $\begin{array}{r}303 \\
1963 \\
2266\end{array}$ & $\begin{array}{r}8 \cdot 8 \\
28 \cdot 7 \\
22 \cdot 0\end{array}$ \\
\hline Total England & 32328 & 3390 & $10 \cdot 5$ & 29501 & 3413 & $11 \cdot 6$ \\
\hline $\begin{array}{l}\text { Scotland } \\
\text { Wales } \\
\text { N Ireland } \\
\text { Total Britain }\end{array}$ & $\begin{array}{l}2822 \\
1092 \\
\mathrm{ND} \\
36242 \\
\text { (176 clinics) }\end{array}$ & $\begin{array}{r}115 \\
44 \\
\text { ND } \\
3549\end{array}$ & $\begin{array}{c}4 \cdot 1 \\
4 \cdot 0 \\
\text { ND } \\
9 \cdot 8\end{array}$ & $\begin{array}{c}3478 \\
591 \\
256 \\
33826 \\
\text { (178 clinics) }\end{array}$ & $\begin{array}{r}216 \\
43 \\
15 \\
3687\end{array}$ & $\begin{array}{r}6 \cdot 2 \\
7 \cdot 3 \\
5 \cdot 9 \\
10 \cdot 9\end{array}$ \\
\hline
\end{tabular}

$\mathrm{ND}=$ no data

TABLE II Homosexual infections in relation to decreased numbers of gonococcal infections 1516

\begin{tabular}{lccccc} 
& & \multicolumn{3}{l}{ Difference } \\
\cline { 4 - 6 } Type of infection & 1971 & 1977 & No & $\% *$ \\
\hline Penile & 1945 & 1904 & -41 & \\
Ano-rectal & $1604 \dagger$ & $1726 \neq$ & +122 & \\
Oral only & ND & 57 & $(+57)$ & \\
Total homosexual & 3549 & 3687 & +138 & +3.9 \\
Total heterosexual & 32693 & 30139 & -2554 & -7.8 \\
Total cases & 36242 & 33826 & -2416 & -6.7 \\
\hline
\end{tabular}

* \% of 1971 infections

$+45 \cdot 2 \%$ of all homosexual infections

$\neq 46.8 \%$ of homosexual infections

$\mathrm{ND}=$ no data

\section{EARLY SYPHILIS}

Osler, in $1897,{ }^{17}$ while admitting that oral chancres arose as a rule from "improper practices," made no reference to rectal lesions. Stokes and his colleagues in $1945,{ }^{19}$ however, gave an excellent description of anal chancres, "which usually resulted from pederasty," but chancres of the lip, gum, tonsil, nasal septum, finger and hand, and skin took precedence. Others considered that these usually arose from the "ordinary osculatory salute" and the "'baiser d'amour"'.19

As with gonorrhoea, the first impact of increasing numbers of recognised ano-rectally acquired infections with syphilis was in London. Between 1932 and 1960 only 60 cases were seen in the outpatient department of St Mark's Hospital, ${ }^{20}$ but within a few years in several venereal disease clinics the percentage of infections with early syphilis which were homosex- ually acquired ranged between 14 and $79 \%{ }^{14}$ with a marked recent increase in the West End. ${ }^{13}$

The investigations of the British Co-operative Clinical Group in $1971^{15}$ and in $1977^{16}$ also concerned primary and secondary syphilis. In 1971, when 924 such cases were studied, the percentages of infections believed to have been homosexually acquired were consistently higher than those for gonorrhoea$\mathbf{9 . 5 \%}$ for Wales, $13.5 \%$ for Scotland, and $25 \cdot 1 \%$ for England (excluding London), and $37 \cdot 2 \%$ for London (excluding the West End) and $73 \cdot 3 \%$ for the five clinics in the West End. 15

By 1977, when 1363 cases were studied, the percentages of homosexually acquired infections in Wales, Northern Ireland (not previously included), and Scotland were $14 \cdot 0,22 \cdot 2$, and $32 \cdot 4 \%$ respectively while in England alone (excluding London) (as in Scotland) it had more than doubled to $52 \cdot 2 \%$ (table III). In London (excluding the West End) the figure was $37.9 \%$ and in the five West End clinics as high as $76 \cdot 9 \% .^{16}$

The increase in homosexually acquired infections has affected all areas. Even in English towns of less than 50000 population the percentage of homosexually acquired infections had risen from $9.5 \%$ in $1971^{15}$ to $43 \cdot 5 \%$ in $1977,{ }^{16}$ when only $46 \cdot 7 \%$ of homosexually acquired infections in Britain (344 of 736) were treated in London compared with $74 \%$ (290 of 392) in 1971 (table III).

The homosexuals have made a big impact on trends. Of the increase of 439 cases between the two studies, $21 \cdot 6 \%$ was accounted for by infections in heterosexuals while no less than $78.4 \%$ of the increase was due to homosexually acquired infections (table IV). 
TABLE III Homosexually acquired infections with primary and secondary syphilis 1516

\begin{tabular}{|c|c|c|c|c|c|c|}
\hline \multirow[b]{3}{*}{ Area } & \multicolumn{3}{|l|}{1971} & \multicolumn{3}{|l|}{1977} \\
\hline & \multirow{2}{*}{$\begin{array}{l}\text { Total } \\
\text { infections }\end{array}$} & \multicolumn{2}{|c|}{ Homosexually acquired } & \multirow{2}{*}{$\begin{array}{l}\text { Total } \\
\text { infections }\end{array}$} & \multicolumn{2}{|c|}{ Homosexually acquired } \\
\hline & & No & $\%$ & & No & $\%$ \\
\hline $\begin{array}{l}\text { England } \\
50000 \text { or less } \\
50001-100000 \\
100001-500000 \\
500001 \text { plus } \\
\text { Total outside London }\end{array}$ & $\begin{array}{r}21 \\
70 \\
171 \\
101 \\
363\end{array}$ & $\begin{array}{r}2 \\
20 \\
52 \\
17 \\
91\end{array}$ & $\begin{array}{r}9 \cdot 5 \\
28 \cdot 6 \\
30 \cdot 4 \\
16 \cdot 8 \\
25 \cdot 1\end{array}$ & $\begin{array}{r}69 \\
130 \\
311 \\
157 \\
667\end{array}$ & $\begin{array}{r}30 \\
61 \\
181 \\
76 \\
348\end{array}$ & $\begin{array}{l}43 \cdot 5 \\
46 \cdot 9 \\
58 \cdot 2 \\
48 \cdot 4 \\
52 \cdot 2\end{array}$ \\
\hline $\begin{array}{l}\text { London } \\
\text { Outside West End } \\
5 \text { West End clinics } \\
\text { Total London }\end{array}$ & $\begin{array}{l}145 \\
322 \\
467\end{array}$ & $\begin{array}{r}54 \\
236 \\
290\end{array}$ & $\begin{array}{l}37 \cdot 2 \\
73 \cdot 3 \\
62 \cdot 1\end{array}$ & $\begin{array}{l}153 \\
372 \\
525\end{array}$ & $\begin{array}{r}58 \\
286 \\
344\end{array}$ & $\begin{array}{l}37 \cdot 9 \\
76 \cdot 9 \\
65 \cdot 5\end{array}$ \\
\hline Total England & 830 & 381 & $45 \cdot 9$ & 1192 & 692 & $58 \cdot 1$ \\
\hline $\begin{array}{l}\text { Scotland } \\
\text { Wales } \\
\text { N Ireland } \\
\text { Total Britain }\end{array}$ & $\begin{array}{l}52 \\
42 \\
\text { ND } \\
924 \\
\text { (176 clinics) }\end{array}$ & $\begin{array}{r}7 \\
4 \\
\text { ND } \\
392\end{array}$ & $\begin{array}{r}13 \cdot 5 \\
9 \cdot 5 \\
\mathrm{ND} \\
42 \cdot 4\end{array}$ & $\begin{array}{r}105 \\
57 \\
9 \\
1363 \\
\text { (178 clinics) }\end{array}$ & $\begin{array}{r}34 \\
8 \\
2 \\
736\end{array}$ & $\begin{array}{l}32 \cdot 4 \\
14 \cdot 0 \\
22 \cdot 2 \\
54 \cdot 0\end{array}$ \\
\hline
\end{tabular}

ND = no data

TABLE IV Homosexual infections and increased number of cases of primary and secondary syphilis 1516

\begin{tabular}{lllll} 
& & \multicolumn{3}{c}{ Increase } \\
\cline { 5 - 6 } Type of infection & 1971 & 1977 & No & $\%^{*}$ \\
\hline Homosexual & & & & \\
Penile & 172 & 355 & 183 & $41 \cdot 7$ \\
Ano-rectal & $220+$ & $366 \neq$ & 146 & $33 \cdot 3$ \\
Oral only & ND & 15 & $(15)$ & $(3 \cdot 4)$ \\
Total homosexual & 392 & 736 & 344 & $78 \cdot 4$ \\
Total heterosexual & 532 & 627 & 95 & $21 \cdot 6$ \\
Total cases & 924 & 1363 & 439 & $100 \cdot 0$ \\
\hline
\end{tabular}

*\% of total increase

$+56 \cdot 1 \%$ of all homosexual infections

$\$ 49 \cdot 7 \%$ of homosexual infections

$\mathrm{ND}=$ no data

\section{Other STDs and the rectum}

\section{BACTERIAL DISEASES}

Group B $\beta$-haemolytic streptococci may affect the anus and surrounding skin in both homosexuals and heterosexuals.

Ano-rectal infection with Neisseria meningitidis is, however, significantly more frequent in homosexual men than in heterosexual women; the more common practice of oro-anal sexual contact among male homosexuals is a likely factor. ${ }^{21}$

Donovanosis (granuloma inguinale) affecting the skin around the anus is nearly always a consequence of passive pederasty. In a review of 48 anal cases in 1958, 44 patients admitted to this practice. ${ }^{22}$ The causative organism, a Gram-negative bacterium, has been considered to be a faecal pathogen, which may be transferred from one individual to another but may also result in autoinoculation of the same person if transferred from the bowel to the anal skin. ${ }^{23}$

A higher incidence of shigellosis has been noted among those who practise oro-genital and oro-anal sex, especially homosexual men $^{24}$ and those who adopt so-called "alternative life styles". ${ }^{25}$ Indeed typhoid fever has been reported to be transmitted in this way. ${ }^{26}$

\section{CHLAMYDIAL DISEASES}

Since its first recognition as a clinical entity inflammatory stricture of the rectum due to lymphogranuloma venereum was regarded as of venereal origin; it was noted that prostitutes were particularly vulnerable, but it was at first by no means generally related to sodomy. ${ }^{18}$ Indeed, although numerous authors have emphasised the role of pederasty in this condition $^{22}$ even some recent reports have been divided in this respect. ${ }^{27}$ Nevertheless it has been recommended that, on the basis of a high incidence of positive results in the Frei and complementfixation tests on patients with a present or past history of peri-rectal abscess or fistula-in-ano especially in male homosexuals, lymphogranuloma venereum must be considered in the differential diagnosis of these conditions. ${ }^{28}$

Non-specific proctitis in men (usually diagnosed $\underset{2}{2}$ when pus cells but no gonococci are found in the 0 rectum) is a relatively common condition in sexually transmitted disease clinics, although it is grouped with nongonococcal urethritis as non-specific genital infection in the official statistics. Chlamydia trachomatis can be isolated in some such cases, ${ }^{29}$ and these infections can be considered to be common in homosexuals. 
FUNGAL DISEASES

Candidosis not infrequently affects the rectum of both sexes; this does not usually result from sexual intercourse but from the taking of antibiotics. Rectal burning and irritation, the then so-called "ano-rectal syndrome," was first described after the ingestion of tetracyclines. ${ }^{30}$ Moniliasis also affects the skin of the perianal region and nates.

\section{PARASITIC DISEASES}

Scabies can be contracted no less easily during homosexual than heterosexual intercourse, although pediculosis pubis would be expected to have a heterosexual bias. Infestation with threadworms (Enterobius vermicularis) has been described in homosexual pairs. ${ }^{31}$

\section{PROTOZOAL DISEASES}

The commonest sexually transmitted protozoal pathogen, Trichomonas vaginalis, seems not to flourish in the rectum. ${ }^{32}$ Amoebiasis, on the other hand, may be manifested by peri-anal and genital ulceration in areas where the condition is endemic. ${ }^{33}$ It may also be passed during homosexual practices, particularly oro-anal contact, ${ }^{2534-36}$ and in nonendemic areas like New York City most cases may be homosexually acquired. ${ }^{36}$ Cases of giardiasis similarly transmitted have also been reported. ${ }^{24} 37$

\section{TRAUMATIC CONDITIONS}

Foreign bodies no less bizarre than those occasionally found in the vagina are sometimes recovered from the rectum, and severe injuries, even fatalities, have occurred after the insertion of bottles and other hard objects. ${ }^{38}$ The author's experience has mainly been associated with vegetables, including a large Spanish onion in the vagina ${ }^{39}$ and a half-peeled cucumber in the rectum. ${ }^{38}$

More recently, so-called "social injuries of the rectum" have included cases of mucosal laceration and bleeding, suspected intra-peritoneal perforation, and extensive injury to the sphincter resulting in complete anal incontinence, which usually occurs in more experienced homosexual men under the influence of drugs who have practised "fist fornication". 40

\section{VIRAL DISEASES}

The large majority of patients of both sexes with anal warts (condylomata acuminata) admit to anal intercourse and this association was well known in Roman times, when they were known as figs. ${ }^{41}$ As penile warts may often be found in sexual contacts of those with anal warts it has been suggested that the condition is not necessarily sexually transmitted but could conceivably result from carriage of the virus in the intestinal tract with subsequent transfer to the anal region during anal intercourse ${ }^{41}$ in a manner similar to that suggested for granuloma inguinale. ${ }^{23}$

The virus of herpes simplex may cause peri-anal vesicles as well as involvement of the rectal mucosa, causing severe rectal pain, tenesmus, diarrhoea, and constitutional symptoms severe enough to warrant admission to hospital. ${ }^{42}$ Both genital and anal herpes may occasionally result in retention of urine with localised neurological signs. ${ }^{43}$

Another disease commonly transmitted by sexual intercourse is viral hepatitis. Since first reports indicating a 10-fold greater carriage rate of Australia antigen in homosexual than in heterosexual patients attending STD clinics, ${ }^{44} 45$ several workers have found a high percentage of homosexuals among patients with hepatitis $B$ infections. ${ }^{25}$ In parts of some cities-for example, New York-most infections with all forms of viral hepatitis in some areas are homosexually acquired. ${ }^{36}$ The precise mode of infection with the hepatitis B virus in these cases remains uncertain but both men ${ }^{46}$ and women ${ }^{47}$ have a higher rate of detection of antigen or antibody according to the number of previous sexual partners.

\section{Discussion}

The practice of anal intercourse is of long standing. Peruvian pottery indicates that this type of activity was well known in ancient times. ${ }^{3}$ Attitudes to it have varied at different periods and in different societies, and a considerable change in attitude has occurred in recent decades.

While the very considerable increase of recognised sexually transmitted diseases which are homosexually acquired is obvious, much of it could well be due to a greater freedom of homosexuals to discuss their infections as a result of a relaxation of the laws regarding homosexuality in many countries. Just over 20 years ago, Marmell in New York City wrote, "Considering the attitude of Western civilizations towards homosexual practices, it is understandable that some patients should be unwilling to admit pederasty. Natural reticence may be involved, but fear of the police, fear of the army courts martial, fear of loss of job or prestige, fear of being branded a 'security risk,' amongst other factors, are powerful and, at times, insurmountable deterrents to an admission of homosexuality." 22

Today, with relaxation of the laws, the freedom to speak is now much greater and is indeed demanded. The term "gay bowel syndrome" has been coined for the variety of rectal conditions presenting to the proctologist including, in descending order of frequency, condyiomata acuminata, haemorrhoids, non-specific proctitis, fistula, peri-rectal abscess, 
anal fissure, amoebiasis, benign polyps, viral hepatitis, gonorrhoea, syphilis, ano-rectal trauma and foreign bodies, shigellosis, rectal ulcers, and lymphogranuloma venereum, which, although by no means exclusive to homosexuals, are found more frequently in this group. ${ }^{48}$

The most notable epidemiological factor in the spread of sexually transmitted diseases among male homosexuals is the high frequency of partner change, a sizable minority of the group repeatedly making their casual contacts in parks, public toilets, baths, and other public places. A moderately active homosexual may easily have contact with 100 different partners a year, ${ }^{4 b}$ often from a variety of different countries, both at home and abroad. In one series $30 \%$ had female contacts as well. ${ }^{49}$

\section{References}

1. Kinsey AC, Pomeroy WB, Martin CE. Sexual Behaviour in the Human Male. Philadelphia and London: WB Saunders, 1948.

2. Hart G. Sexual Maladjustment and Disease. Chicago: Nelson Hall, 1977.

3. Goldberg J. Studies on granuloma inguinale. VII Some epidemiological considerations of the disease. Br J Vener Dis 1964; 40: 140-5.

4a. Cornthwaite SA, Savage WD, Willcox RR. Oral and rectal coitus amongst female gonorrhoea contacts in London. $\mathrm{Br} \mathrm{J}$ Clin Pract 1974; 28: 305-6.

4b. Gebhard PH. The exposure factor. The VD Crisis: Report of International Venereal Disease Symposium, St Louis, Mo. New York: Pfizer Laboratories, 1971.

5. Nicol CS. Some aspects of gonorrhoea in the female-with special reference to infection of the rectum. $B r J$ Vener Dis 1948; 24:26-37.

6. Martin CL. Rectal gonorrhoea in women. JAMA 1935; 104: $192-4$.

7. Clements PA, Hughes KEA. The incidence of proctitis in gonorrhoea of females. Lancet 1935; ii: 18-9.

8. Pelouze PS. Gonorrhoea in the Male and Female. 3rd ed. Philadelphia and London: WB Saunders, 1939.

9. Jensen T. Rectal gonorrhoea in women. Br J Vener Dis 1953; 29:222-34

10. Morson BC. Anorectal venereal disease. Proc R Soc Med 1964; 57: $179-80$.

11. Harkness AH. Anorectal gonorrhoea. Proc R Soc Med 1948; 41:476-8.

12. McLachlan AEW. Handbook of Diagnosis and Treatment of Venereal Diseases 4th ed. Edinburgh: Livingstone, 1951:295.

13. Fluker JL. Recent trends in homosexuality in West London. $B r$ $J$ Vener Dis 1966; 42:48-9.

14. Jefferiss FJG. Homosexually acquired venereal disease. $\mathrm{Br} \boldsymbol{J}$ Vener Dis 1966; 42:46-7.

15. British Cooperative Clinical Group. Homosexuality and venereal disease in the United Kingdom. Br J Vener Dis 1973; 49: 329-34.

16. British Cooperative Clinical Group. Homosexuality and venereal disease in the United Kingdom-a second study. Br $J$ Vener Dis 1980; 56:6-11.

17. Osler W. The Principles and Practice of Medicine. 2nd ed. Edinburgh and London: Young J Pentland, 1897.

18. Stannus HS. A Sixth Venereal Disease. Climatic bubo, lymphogranuloma inguinale, Esthiomène, chronic ulcer and elephantiasis of the genito-ano-rectal region, inflammatory stricture of the rectum. London: Ballière, Tindall and Cox, 1933.

19. Stokes JH, Beerman H, Ingraham NR. Modern Clinical Syphilology. 3rd ed. Philadelphia: WB Saunders, 1945.
20. Hollings RM. Syphilitic ulcers of the anus. Proc $R$ Soc Med 1961;54:730-1.

21. Judson FN, Ehret JM, Eickhoff TC. Anogenital infection with Neisseria meningitidis in homosexual men. $J$ Infect Dis 1978; 137:456-63.

22. Marmell $M$. Donovanosis of the anus in the male-an epidemiological consideration. Br J Vener Dis 1958;34:213-8.

23. Goldberg J, Bernstein R. Studies on granuloma inguinale. VI Two cases of perianal granuloma inguinale in male homosexuals. Br J Vener Dis 1964;40: 137-8.

24. Mildran D, Gebb AM, William D. Venereal transmission of enteric pathogens in male homosexuals. JAMA 1977;238: $1387-9$.

25. Ainsworth TE, Back A, Boucher LA, Garrard WF, Palmer RD, River E. Patterns of sexually transmitted enteric disease. Lancet 1977; ii: 3-4.

26. Dritz SK, Bratt EH. Sexually transmitted typhoid fever. $N$ Engl J Med 1977;296: 1359-60.

27. Willcox RR. Lymphogranuloma venereum. In: Morton RS Harris JRW, eds. Recent Advances in Sexually Transmitted Diseases. Edinburgh, London and New York: ChurchillLivingstone, 1975: 188-93.

28. Greaves AB. Frequency of lymphogranuloma venereum in persons with perirectal abscesses, fistulae-in-ano, or both: with particular reference to the relationship between perirectal abscesses of lymphogranuloma origin in the male and inversion. Bull WHO 1963;29:797-801.

29. Dunlop EMC, Jones BR, Al Hussaini MK. Genital infection in association with TRIC virus infection of the eye. III Clinical and other findings. Preliminary Report. $\mathrm{Br} J$ Vener Dis 1964; 40:33-42.

30. Willcox RR. Anorectal syndrome and other side-effects of Terramycin. Lancet 1951; ii: 154-6.

31. Waugh MA. Sexual transmission of intestinal parasites. $\mathrm{Br} J$ Vener Dis 1974;50:157.

32. Trussell RE. Trichomonas vaginalis and Trichomoniasis. Springfield, Ill: CC Thomas, 1947.

33. Heinz KDW. Amoebic infection of the female genital tract. Report of three cases. S Afr Med J 1973;47: 1795-8.

34. Rabb RR. Sexually transmitted infections in homosexual men. Postgrad Med J 1979;65:211-22.

35. Schmerin MJ, Gelston A, Jones TC. Amoebiasis: an increasing problem amongst homosexuals in New York City. JAMA 1977; 238: 1386-7.

36. William DC, Felman YM, Marv JS, Shookhoff HB. Sexually transmitted enteric pathogens in a male homosexual population. NY State J Med 1978; 77:2050-2.

37. Meyers JD, Kuharic A, Holmes KK. Giardia lamblia infection in homosexual men. Br J Vener Dis 1977; 53:54-5.

38. Willcox RR. Rectal foreign bodies. Medical Press 1952; No 5896: 443-4.

39. Willcox RR. An unusual case of vaginal tumour. $\mathrm{Br} J$ Vener Dis 1961;37:284.

40. Sohn N, Weinstein MA, Gonchar J. Social injuries of the rectum. Amer J Surg 1977; 134:611-2.

41. Oriel JD. Anal warts and anal coitus. Br J Vener Dis 1971;47: 373-6.

42. Curry JP, Embil JA, Williams CN, Manual FR. Proctitis associated with herpes virus hominis type 2 infection. Can Med Assoc $J$ 1978; 119:485-6.

43. Oates JK, Greenhouse PR. Retention of urine in anogenital herpetic infection. Lancet 1978; i:691-2.

44. Fulford KWM, Dane DS, Catterall RD, Woof, S, Denning JV. Australia antigen and antibody among patients attending a clinic for sexually transmitted diseases. Lancet 1973; i: 1470-3.

45. Jeffries DJ, James WH, Jefferiss FJG, Macleod KG, Willcox RR. Australia (hepatitis-associated) antigen in patients attending a venereal diseases clinic. Br Med J 1973; ii: 455-6.

46. Lim KS, Wong VT, Fulford KWM, Catterall RD, Briggs M, Dane DS. Role of sexual and non-sexual practices in the transmission of hepatitis B. Br J Vener Dis 1977; 53: 190-2.

47. Frosner GC, Buckholz HM, Gerth H-J. Prevalence of hepatitis B antibody in prostitutes. Amer J Epidemiol 1975; 102:241-50.

48. Sohn N, Robilotti JC. The gay bowel syndrome: a review of colonic and rectal conditions in 200 male homosexuals. Amer J Gastroenterol 1977;67:478-84.

49. Judson PN, Miller KG, Schaffnit TR. Screening for gonorrhoea and syphilis in the gay baths, Denver, Colorado. Amer J Public Health 1977;67:740-2. 